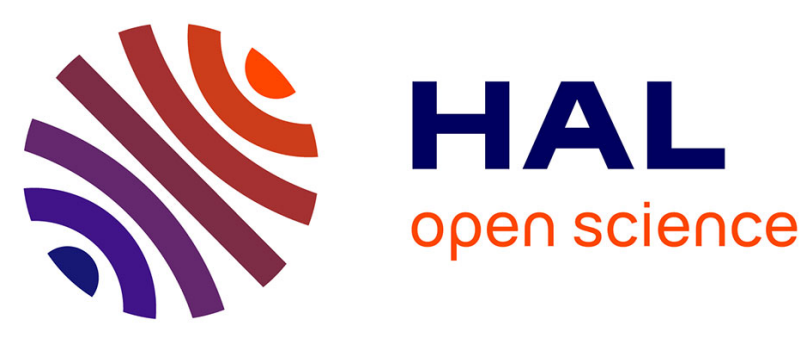

\title{
FROM RISK TO LEGISLATIVE INNOVATION: THE TRAJECTORY OF MARINE SUBMERSION THROUGH THE FRENCH MEDIA
}

Solveig Lelaurain, Séverin Guignard, Alexandra Schleyer-Lindenmann, Raquel Bertoldo

\section{To cite this version:}

Solveig Lelaurain, Séverin Guignard, Alexandra Schleyer-Lindenmann, Raquel Bertoldo. FROM RISK TO LEGISLATIVE INNOVATION: THE TRAJECTORY OF MARINE SUBMERSION THROUGH THE FRENCH MEDIA. Environmental Communication, inPress, pp.1-17. 10.1080/17524032.2021.1954538 . hal-03327536

\section{HAL Id: hal-03327536 https://hal.science/hal-03327536}

Submitted on 27 Aug 2021

HAL is a multi-disciplinary open access archive for the deposit and dissemination of scientific research documents, whether they are published or not. The documents may come from teaching and research institutions in France or abroad, or from public or private research centers.
L'archive ouverte pluridisciplinaire HAL, est destinée au dépôt et à la diffusion de documents scientifiques de niveau recherche, publiés ou non, émanant des établissements d'enseignement et de recherche français ou étrangers, des laboratoires publics ou privés. 
FROM RISK TO LEGISLATIVE INNOVATION: THE TRAJECTORY OF MARINE SUBMERSION THROUGH THE FRENCH MEDIA

Solveig Lelaurain ${ }^{1,2}$, Séverin Guignard ${ }^{1}$, Alexandra Schleyer- Lindenmann ${ }^{1}$, Raquel Bertoldo ${ }^{1,2}$

${ }^{1}$ Aix Marseille Univ, Université Côte d'Azur, Avignon Université, CNRS, ESPACE, UMR 7300, Avignon, France

${ }^{2}$ Aix Marseille Univ, LPS, Aix en Provence, France

Correspondence concerning this manuscript should be addressed to Solveig Lelaurain,

Laboratoire de Psychologie Sociale, Aix-Marseille Université, 29 avenue Robert Schuman, 13621 Aix-en-Provence, France. Email: solveig.lelaurain@gmail.com 


\section{Abstract:}

Storm Xynthia (2010) brought to the fore marine submersion as a great concern to French authorities and communities. This storm illustrates how a single major event can have long lasting effects on climate risk management. To discern this effect, we conduct two studies analysing the emergence and evolution of concerns related to marine submersion in French national and regional newspapers prior to and after the storm (2005-2018). In Study 1, we examine trends in issue coverage and how 'marine submersion' was appropriated by French media discourse over the selected period, identifying and segmenting specific topical sequences. In Study 2, a computer-assisted content analysis of 260 articles highlights a dichotomy of themes before and after Storm Xynthia. Articles published prior to Xynthia (2005-2009) warned of marine submersion among the expected impacts of climate change. Those published just after Xynthia (20102013) present highly structured and technical descriptions of national risk management policies. In recent years (2014-2018), articles focus on local stakeholders' challenge to national risk management policies, described as too far removed from local dynamics. Our studies reveal the emergence and amplification, via public debate in French newspaper media, of 'marine submersion' as a hazard, and the objectification of the risk through Storm Xynthia.

Keywords: coastal flooding; emerging risk; media representations; legal innovation; climate change 


\section{Introduction}

On the night of 27-28 February 2010, Storm Xynthia flooded 55 cities and 50,000 hectares of land on the French Atlantic coast. Forty-seven persons lost their lives, 41 of them by drowning. Existing databases indicate that no marine submersion event recorded in France has ever resulted in more casualties (Garnier \& Surville, 2010). That day, Xynthia brought an unprecedented threat from the sea to French society, placing marine submersion at the centre of concerns of policy makers (Chadenas et al., 2014; Prieur \& Leost, 2015), researchers (Breilh et al., 2013; Chaumillon et al., 2017; Creach et al., 2015; Kolen et al., 2010; Vinet et al., 2012), legal experts (Mulot, 2015) as well as of (potentially) affected communities (Michel-Guillou et al., 2015).

Storm Xynthia brought the limits of coastal risk management models into view for French society: such an event had not yet been thought possible for that region. But once that dramatic event was experienced for the first time, society as a whole went through a collective symbolic effort to understand the event (Michel-Guillou et al., 2015), to adapt to the tragedy and to seek to avoid similar events that could hit France's western seaboard in the future (Vinet et al., 2012). This collective meaning making involves institutional changes which are both a result of and a trigger for renewed collective debates (Castro \& Mouro, 2016).

A parallel can be drawn here with the 2003 heatwave that impacted France (Poumadère et al., 2005): the fact that such an event was not imaginable until that point in time rendered this particular hazard invisible to public administrations. After 2003 however, through a process of societal meaning making and institutional adaptation, risk management strategies significantly reduced the human vulnerability to more recent, and stronger, heatwaves (Fouillet et al., 2008). 
In this sense, we consider Storm Xynthia a traumatic event that triggered collective coping strategies (Navarro et al., 2020) based on shared representations (Krien \& Michel-Guillou, 2014) and institutional change (Castro, 2012). Yet, to our knowledge, little research has explored whether and how collective meaning making about coastal flood events has accompanied institutional adaptation (see, however, Krien \& MichelGuillou, 2014).

Considering the longitudinal aspect of the problem we turn to the written press as a means to explore collective meaning making under a temporal and comparative perspective (e.g., Caillaud et al., 2011). "As a forum for the discourses of others and a speaker in their own right, the media have a key part in the production and transformation of meanings" (Carvalho, 2007, p. 224).

In this article we present two press analytic studies with the goal of illustrating how the public understanding of marine submersion risk has evolved through the collective experience of Storm Xynthia: from an invisible hazard (Vinet et al., 2012) to a pillar of coastal risk management strategies (Chadenas et al., 2014). This analysis will describe the emergence and evolution of this 'new' risk in French media (Study 1) and the type of discourse associated with each period and at different administrative levels local vs. national (Study 2) (cf. Castro et al., 2011). We begin by outlining the theoretical framework used to analyse the emergence of "marine submersion" as a new risk: the Social Amplification of Risk Framework (SARF) (Kasperson et al., 1988). Then, we will present the two models used to support our longitudinal newspaper media analysis: the media issue-attention cycle (Downs, 1972) and the temporal approach to normative social change in legal matters (Castro, 2012).

\section{Social amplification of 'natural' risks}


Despite the well-documented winter storms that hit the French coasts each year (Poumadère et al., 2015), coastal floods were formerly relatively disregarded by public administrations. One example of this relative invisibility of coastal risks before Storm Xynthia in 2010 is the absence of marine submersion as a risk category capable of triggering state response (Calvet \& Manable, 2015). In this sense Storm Xynthia has profoundly changed the way institutions deal with these once normalized seasonal events (Bertoldo, 2021). This particular understanding of how a single storm may, though ripple effects, engender important and irreversible changes in how a society understands risk is supported by the Social Amplification of Risk Framework - SARF (Kasperson et al., 1988).

The SARF was initially proposed as an integrative approach in risk research to illustrate how social, economic and psychological factors dynamically overlap to increase the public perception of and response to a hazard (Kasperson et al., 1988; Pidgeon et al., 2003). The SARF uses the signal amplification concept of communication theory to describe how risk information travels and is transformed through its relay between stations (e.g., scientists, institutions, media, activists) (Kasperson et al., 1988, p.180). The framework thus highlights how communication stations intensify or attenuate 'risk signals' over their successive transmission until they reach the final receivers (DeFleur, 1966; Kasperson et al., 1988).

Still, Kasperson et al. (1988) among other critics (Bakir, 2005; Burgess, 2012) recall that the amplification metaphor, borrowed from the theory of communication, is far more simplistic than the risk phenomena as they take place in modern societies because "messages have a meaning for the receiver only within a sociocultural context" (Kasperson et al., 1988, p. 180, added italics). 
Therefore, by understanding the communication context as depicted in (and influenced by) the press and social media, we would be more capable of explaining why some "amplification stations" increase (social risk amplification) while others reduce (social risk attenuation) the signal of the information associated with specific risks (Breakwell, 2014). These 'stations' interpret information according to already available symbols and images, which leads to particular understandings and consecutive responses by other participants in the social system (Kasperson et al., 2003). The addition or subtraction of cultural symbols by any of these amplification stations can therefore alter the public attention that will be given to a particular risk episode (Kasperson et al., 1988). Understanding this cultural background is therefore of utmost importance when analysing the potential for amplification or attenuation of an event.

The SARF in this way lends texture to the understanding of a coastal risk event as not simply involving a "natural" hazard, but rather as an interaction of natural forces and the human (built) environment, human influence (anthropogenic climate change), and finally societal processes of meaning making and response.

\section{Temporal approaches and the emergence of marine submersion as a societal issue}

An analysis of how Storm Xynthia emerged in the media as an issue capable of changing how French society deals with coastal risks calls for understanding social change as a longitudinal process. We therefore employ two distinct but complementary temporal approaches. The notion of a media issue-attention cycle (Downs, 1972) is familiar today. Less widely known is the model of legal innovation for normative social change (Castro, 2012). Analysis of how Storm Xynthia changed our institutional response and amplified (Kasperson et al., 1988) this risk also needs to consider how the societal 
debate unfolds in a dynamic relationship with institutional and legal changes (Castro, 2012).

The media issue-attention cycle approach was elaborated by Downs (1972) in order to describe the variations, over time, in the media treatment of societal problems such as environmental risks. Consistently with the SARF, Downs (1972) assumes that there are no intrinsic qualities of an issue that will generate particular media attention; this is rather the fruit of the way mass media interact with the public: mainly through the construction of crisis cycles. According to Downs (1972), a cycle has five stages. A preproblem stage is characterized by a low level of mainstream attention, even though experts or informed citizens have already started to voice concerns. An alarmed discovery stage is characterised by a sudden increase in attention level, as witnessed for example by a sharp rise in the number of published articles. This stage typically suggests a particular event has suddenly alarmed the public and raised awareness of a new issue. Then a maintenance stage is characterised by the upkeep of public concern over the issue and by political action: policies are proposed and implemented. A decline stage follows, characterised by a decline in public interest; and, finally, the post-problem stage reflects the stabilisation of public attention and an occasional return of the issue to the forefront - now presenting the issue through elusive (Neca \& Castro, 2012) comparisons with newer issues.

However, analysing how media attention cycles around Xynthia are accompanied by - or the result of - institutional changes requires the consideration of how legal innovation accompanies emerging societal issues. The institutional transformations that either follow or drive societal debates have been theorized as part of the 'legal innovation for normative social change' (Castro, 2012; Jensen \& Wagoner, 2009). According to 
Castro (2012), social changes triggered by laws and regulations entail complex temporal phenomena that can be analysed through four main phases.

The first one is the emergence phase which corresponds to the rise of concern in society, often through minority movements' activism. Here the spread of discourse can be characterized as 'bottom up' (Castro, 2012). Then, if and when these initially marginal ideas achieve a "certain level of social consensus and legitimacy" (Castro, 2012, p. 108), they may succeed in influencing mainstream politics, starting a second phase: the institutionalisation phase. Here, the "new consensus is translated into a set of legal, policy, and institutional innovations" (Castro, 2012, p. 108). This 'top-down' process of translating initially emergent concerns into institutional innovations often meets locally with resistance and protest, in an effort to locally adapt new regulations and negotiate how these changes might be applied (Castro \& Mouro, 2011). Following their institutionalisation, these legal changes normally have yet to go through a generalisation phase. Here the top-down changes proposed during the previous phase have not yet gained support across society and a mismatch can still be observed between prescriptive norms represented by laws and regulations, and their corresponding descriptive norms (Castro, 2012) that are translated by actual practices. Typically, this phase is characterised by a discontinuity between discourse and practice. This relative mismatch creates resistance but also creates the possibility to negotiate how formal prescriptive norms are to be locally implemented. Concrete negotiations and concessions slow down the social change purposes intended by/through the laws (Castro \& Batel, 2008). Eventually discontinuities between what is prescribed and what is done in context might become perfectly congruent. This utopic state of congruency could be achieved during a fourth phase, the stabilization phase, when discourse and action are coordinated (Castro, 2012) and one might say, integrated into a new background culture. Still, this phase may be long 
to achieve because our democracies live under constant changes and structural adaptations.

\section{Synthesis and studies overview}

Storm Xynthia (2010) confronted French society with the limits of how it imagined and prepared for coastal risks. Considering that this storm was paramount to how French society conceives and responds to coastal risks today, this paper proposes to analyse how the content associated with 'marine submersion' evolved across the different phases of social and institutional changes (Castro, 2012), ultimately contributing to a more efficient climate change adaptation.

Press analysis is a powerful tool to illustrate the evolution of societal debate (Jaspal \& Nerlich, 2012) or to compare how an issue is depicted in the national or local press (Castro et al., 2012). We will analyse the media behaviour in regard to "marine submersion' on the basis of (1) the temporality of publication with reference to the date of Storm Xynthia; and (2) the discursive contents of the published articles. Both analyses will draw on and verify the actual demonstration of the Downs (1972) issue-attention cycles, and the different theoretical phases of "legal innovation for normative social change" (Castro, 2012; Castro \& Batel, 2008; Jensen \& Wagoner, 2009) in climate change adaptation.

Study 1 analyses the different stages (Downs, 1972) and phases (Castro, 2012) describing the emergence and evolution of marine submersion in the French media. Here we examine issue coverage trends over the last 13 years (2005-2018) in eight national and regional newspapers. This study will explore how 'marine submersion', this new category of emerging glocal risks, was appropriated by the French media discourse - 
number of articles and their distributions all along the recent years period, identification and segmentation of specific periods.

Using the specific reporting periods identified in Study 1, Study 2 aims to identify the specificity of the narratives and discursive strategies characterising each period, and which actors' points of view are depicted in the press articles.

\section{Study 1}

This first study aims at describing how the number of articles published in France about marine submersion evolved in relation to Storm Xynthia (2010): before and during the storm and since then. This first description is inspired by how Downs (1972) describes the media attention stages about how an issue is reported; and also by Castro's (2012) four phases model of normative social change. These two temporal frameworks will here be used to support interpretation of the reporting stages of the 'marine submersion' issue in relation to Storm Xynthia in French newspapers.

\section{Methodology}

We selected eight French daily newspapers available on the Factiva database. This choice intended to favour the diversity of newspapers regarding (1) their geographical zone: regional (La Provence, Le Courrier de l'Ouest, Ouest France, Var Matin) vs. national (La Croix, Les Echos, Le Figaro, L'Humanité); and among the regional newspapers, Atlantic (Le Courrier de l'Ouest, Ouest France) vs. Mediterranean coast publications (La Provence, Var Matin); and (2) their a priori ideological orientation: leftwing (L'Humanité) to right-wing (Le Figaro). 
In this database we selected all the articles published between 2005 and 2018 with the following keywords": "marine submersion*”; "submersion*” AND “sea"; "coastal*” AND "submersion"; "submersion*" AND "risk"2.

\section{Results}

[Insert Figure 1 about here]

A total of 3,389 articles was yielded by this keyword database search. Figure 1 highlights how publication frequencies evolved over time. The fewest articles were published in 2006 and the most in 2015 (7 and 599 respectively). Figure 1 shows three phases of press coverage.

Before 2010, press attention to marine submersion in France was almost nonexistent. For this reason, we describe this period as the "emergence phase" (Castro, 2012) or "pre-problem stage" (Downs, 1972), because it corresponds to the moment when the early concerns, still scarce, started to rise about this environmental risk and that it happened before events of the intensity of Xynthia were considered a possibility (Vinet, 2012). During this first pre-Xynthia phase, meteorological phenomena similar to 'marine submersions' were predicted by experts. Few coastal flood phenomena happened in this period and the last "reference storm" dates back to Storm Martin, in 1999. The lack of risk considerations resulted in the growing urbanization of flood-prone areas, producing in itself increased risk (Vinet, 2012).

\footnotetext{
${ }^{1}$ In French: "submersion marine"; "submersion" ET “mer"; "submersion” ET "marine"; "submersion” ET "risque".

2In France, "marine submersion" describes the same phenomenon as "coastal floods". This press analysis solely covers the articles using the institutionally chosen term "marine submersion" and cannot account for all the articles speaking broadly of coastal flooding phenomena.
} 
In 2010, a rise in the number of articles mentioning 'marine submersion' is seen in the months following Storm Xynthia. An early reporting peak is observed in 2011, which corresponds to the announcement of the first risk management plan proposed by the government. This first peak is followed by a stable frequency of articles covering the issue until 2014. Based on these elements we can describe the 2010-2013 period as the "alarmed discovery" stage (Downs, 1972) or the "institutionalisation phase" (Castro, 2012), which corresponds to the particular attention paid to this hazard at the level of both risk perception and legal innovation. This alarmed discovery (Downs, 1972) of coastal risks is interpreted as the re-characterisation of seasonal storms - often 'normalised' phenomena known to coastal communities (Luís et al., 2015) - as dangerous natural hazards.

A second peak of articles mentioning 'marine submersion' emerges well after Storm Xynthia, in the period between 2014 and 2018. This high number of articles seems relatively stable until 2018. Based on the stable frequency of articles about 'marine submersion' and the coincidence of this phase of reporting with the implementation of legal changes, the 2014-2018 period can be described as a "maintenance stage" (Downs, 1972) or as a "generalization phase" (Castro, 2012). However, the fact that the high plateau is observed suggests that another 'newsworthy' event related to Xynthia might be fuelling the frequency of 'marine submersion' reporting during this period, instead of the predicted "maintenance" of the issue. Indeed, article contents focus during this period on the publication of a second risk management plan and also on the particularly wellpublicized trial of public and private authorities thought to be responsible for deaths in the aftermath of Storm Xynthia.

In order to better understand the content associated with the pre-Xynthia phase, as well as this second reporting peak starting in 2014, a content analysis will be presented 
in the following study. It will also explore whether reporting mirrors 'institutional social change' for climate change adaptation.

\section{Study 2}

In Study 2 we will analyse in greater detail the narratives, meanings and representations associated with each issue attention stage identified in Study 1 (see Uzelgun \& Castro, 2015). More specifically, the second study will explore the content associated with each of the time periods identified in Study 1. Scale and geographic focus will also be assessed: national press vs. local press (Castro et al., 2011) and Mediterranean vs. Atlantic vs. Channel vs. France in general.

We are interested here in analysing how potentially hazardous coastal events associated with 'marine submersion' are represented through various press articles subsamples - with content related to different geographical locations, different actors, different space issues and different time periods. These analyses will provide a closer description of how a new category of risk - marine submersion - becomes invested with meaning through different phases of institutional legitimacy (Castro, 2012). When newspaper articles report new risks and risk management policies - or on the contrary criticize them - they are endorsing them or their resistance, therefore contributing to an informal gain in legitimacy (Bertoldo \& Castro, 2018) that is pivotal to their success (Castro \& Mouro, 2011). For this reason, understanding the meanings attributed to these new risks in the media, at different reporting levels, will give us a clearer picture of how these risks are represented, and how the climate change adaptation policies are socially legitimised.

\section{Methodology}


A stratified sampling strategy was performed on the article sample analysed in Study $1(n=3,389)$ in order to use a reduced sample of articles. A sampling criterion adapted to each period was adopted in function of the volume of articles published in each period ${ }^{3}$.

Following the methodology of Uzelgun and Castro (2015), for articles published before 2010, one article out of two was selected; from 2010, given the significant increase in the number of articles, one out of six was selected. When the article selected by sampling made only an elusive reference to marine submersion (i.e., when marine submersion was not its central theme) the following pertinent article was chosen. This sampling method left us with 260 articles over 13 years, for use in the subsequent analysis.

\section{Data analysis}

The press environment has been considered to be a privileged space for the emergence of differences in communication styles, in types of engagement with the public and more broadly of ideological orientations (Jaspal \& Nerlich, 2012; Moscovici, 2008). The dialogical nature of social communications in general (Billig, 1988; 1991) and particularly of the press environment (e.g., Jaspal et al., 2012) suggests that content diversity, or debate, emerge in the media around social issues. In the goal of systematically associating this content diversity existing at any point in time with the above-mentioned periods of 'marine submersion' reporting, we opted for a computer-

\footnotetext{
3 "Although we have chosen to perform a computer-assisted analysis with the Iramuteq software (see below the "data analysis" section), considering the large number of press articles $(\mathrm{n}=3,389)$ identified in Study 1 , sampling - a method to reduce - was necessary. Indeed, we did not limit the analysis to the raw results of the software, but coupled it with a thematic content analysis of the corpus as recommended by Kalampalikis (2005). Furthermore, this method requires preparation coupled with an in-depth analysis of the texts (i.e., coding of each article and associated metadata, gathering of words or expressions using a hyphen such as "marine_submersion")."
} 
assisted approach to support our qualitative analysis. The IRaMuTeQ software performs a top-down hierarchical classification following the Reinert method (1983; 1986; see also Kalampalikis, 2003). This classification method is based on chi-square associations between semantic contexts and particular contents, thereby rendering content differences salient. Therefore, this method was seen as particularly useful to explore the diversity of arguments and associate them to 'marine submersion' reporting periods.

The Reinert method consists of a top-down hierarchical classification (DHC) of corpus text segments (i.e., sentences or parts of sentences separated by punctuation with a maximum length of 40 words) which are classified according to lemmatized active forms. Lemmatization means reducing all variants of the same word to a single root: for example, the infinitive of a verb heads the class of conjugated or other verb forms observed in the corpus. Then, phrases or 'discursive context' start to be segmented based on how different they are. This segmentation happens in every context until the discourse within it is considered to be relatively homogeneous. These lexical classes refer to commonplace discursive content that tends to be used together - i.e., within the same phrase (Kalampalikis \& Moscovici, 2005). The word-class association is estimated by a chi-square test, which is calculated from on a contingency table comparing the presence or absence of a word in a sentence and the membership or not of this sentence in the considered class. The higher the chi-square, the stronger the association between a word or variable and a lexical class. Following previous research with the Reinert method using IRaMuTeQ (see Camargo \& Bousfield, 2009; Idoiaga Mondragon \& Belasko Txertudi, 2019; Idoiaga Mondragon et al., 2020; Lelaurain et al., 2018) we selected the most significant vocabulary of each lexical class following three criteria: 1) an expected occurrence of the word greater than $3 ; 2$ ) proof of association of the chi-square with the 
class $\left(\chi^{2} \geq 3.84 ;(p=0.05) ; d f=1\right)$; and 3$)$ the fact that the word is specific to that class in at least half the times it is used.

The Reinert method has frequently been used for media studies (see Britel et al., 2020; Ledouble \& Marty, 2019; Manchaiah et al., 2018) because of its advantages in relation to other lexicometric methods. These advantages can be summed in the following points:

1. Capacity to identify systematic differences in discourse: because the Reinert method employs chi-square it brings up oppositions in frequency and absence of words rather than commonalities. This capacity to select and describe differences is a strong feature of this method that makes it especially suitable for the analysis of the social debate.

2. Capacity to associate lexical classes with contextual variables (metadata): possibility to explore the statistical relationship between the lexical classes and the variables containing metadata, which are "passive" variables - not taken into account in the lexical class calculation.

3. Systematicity: the content analysis procedure is objectifiable and replicable. While the bypass of content interpretation and inductive theory building can be considered a disadvantage if compared to content analysis, it is an interesting feature in that the Reinert method allows all content to be systematically analysed with interpretative bias.

In the context of our study, the Reinert method will allow us to describe the connections between the discursive contents about 'marine submersion' and the variables associated with the press articles' context (described by metadata). In the present case, the metadata were date of publication (2005-2009 vs. 2010-2013 vs. 2014-2018), the newspaper in which the article was published (La Provence vs. Le Courrier de l'Ouest 
vs. Ouest France vs. Var Matin vs. La Croix vs. Les Echos vs. Le Figaro vs. L'Humanité), the type of newspaper (national vs. regional), and the geographical base of the newspaper (Atlantic coast vs. Mediterranean coast vs. Channel coast vs. France in general).

We adopted a triangulation approach in which computer-assisted analysis was interpreted and then content analysed (see Fonte et al., 2017): following the DHC, we started by identifying the different lexical classes, the main ideas, words and variables associated with them. Secondly, within each lexical class we conducted a content analysis, from which sub-themes were identified. Finally, with these elements in mind, we interpreted how the content and variables associated with each of the classes mirror the temporal social change phases described in the introduction.

In order to highlight the "dynamics of the meaning-making processes" (see Uzelgun \& Castro, 2015), we also analysed which actors were mentioned or directly cited in the articles. The actor categories identified included: scientists, national politicians, local politicians, associative stakeholders and inhabitants; the frequency of direct quotations for each category of actors was calculated

\section{Results}

The top-down hierarchical classification (see Figure 2) sorted out 4,040 text segments that were organised around four different lexical classes about marine submersion: (1) "Implementation of national risk management plans"; (2) "Xynthia and coastal storms"; (3) "Impacts of climate change on coastal areas" and (4) "Conflicts and local public debates".

As shown in Figure 2, the corpus divisions that resulted in the above-mentioned classes substantiate the major differences found in the 'marine submersion' discourse typically employed after Storm Xynthia and by the regional, Atlantic press (Classes 1 
and 4); and in discourse typically found before Xynthia, in the national press and related with other regions: channel, Mediterranean, France in general (Classes 2 and 3).

In order to increase the visibility of the associated psychosocial phenomena (e.g., level of national vs. local resistance to climate change adaptation proposals), in the following sections we present the discourse classes chronologically according to the publication period with which they are significantly associated.

[Insert Figure 2 about here]

Impacts of climate change on coastal areas (Class 3)

Impacts of climate change on coastal areas (Class 3), represented 863 text segments (21.36\% of the analysed corpus) and was associated with the following variables: "years of publication 2005-2009" $(\chi 2=257.07)$ and "national newspapers" $(\chi 2=106.02)$. More specifically, among newspapers associated with this class we find: "La Provence" ( $\left.\chi^{2}=71.06\right)$, "La Croix" $\left(\chi^{2}=39.35\right)$, "Le Figaro" $\left(\chi^{2}=34.68\right)$, "L'Humanité" $\left(\chi^{2}=11.53\right)$, "Le Courrier de l'Ouest" $\left(\chi^{2}=8.68\right)$ and "Les Echos" $\left(\chi^{2}=\right.$ 6.05). This class was also associated with the variables "Mediterranean coast" $(\chi 2=$ 85.69), "Channel coast" $(\chi 2=69.98)$ and "France in general" $(\chi 2=72.48)$.

Discourse significantly associated with this class, is typical of scientists ${ }^{4}$ who sound the alarm by warning about the effects of global warming / climate change on coasts, in particular on the rise of the sea level, the retreat of the dune barrier and the phenomenon of erosion. Many terms used to describe the coastline are thus found such as: beach, sand, cliff or coastal line. In addition, several press articles report the results of studies carried out to estimate, on the one hand, the extent of this phenomenon,

${ }^{4}$ Terms in italics are those significantly associated with each class. 
frequently employing a technical-scientific vocabulary - i.e., modelling, laser, tide gauge, topographic - and, on the other hand, its future consequences, as indicated by the temporal markers characteristic of this class: 2100, 2050, evolution, horizon and anticipation. Here are excerpts that are typical of the content in this class:

A study presented yesterday by the Coastal Protection Agency precisely measures the impact on beaches, dunes, cliffs, polders or salt meadows. On sandy coasts, it is spectacular: the retreat could reach several dozens of metres by 2100. (Ouest France, 2005)

The sea rises, Brittany will shrink. Was the eruption of the 2001 waves, and especially during the 8 March 2008 storm, just a prelude to what global warming is preparing? Will Brittany have to give up a few square kilometres to the ocean? "At the beginning of the decade, the sea was expected to rise by thirty centimetres in one century," recalls Philippe Sergent, Scientific Director of the Cetmef 5 . (Ouest France, 2009)

Experts' cautionary tone also raises questions about future strategies to protect, fight and mitigate this phenomenon. Different visions are thus discussed and debated within the press articles: "fight against it? Let it go? Accompany it?", "Building concrete barriers or giving in to the sea?". More precisely, there are two opposing views: the so-called soft methods, the more natural ones, such as the creation, rehabilitation or fattening of dunes, relocation, retreat or abandonment; and the so-called hard ones, such as concreting, creating dikes made of riprap, or building breakwaters. Here are some examples of this discursive content:

${ }^{5}$ Centre d'étude maritime et fluviale de l'Équipement (Centre for Maritime and River Studies) 
Scientists agree, however, on the risks involved. Since the 1990s, the level of the Mediterranean Sea has been rising by 2.5 to 10 millimetres a year. [...] The "Grenelle de la mer",", held in 11 regions, has thus crystallized here around which strategy is best to adopt. "Are we going to have to relocate 10, 20 or $30 \%$ of our population?". Two visions clash: maintain the existing coastline or move back. (La Croix, 2009)

[...] A compromise between marine engineers' hard, passive methods and naturalists' softer, active methods. The former generally require less investment but are more expensive to maintain, unlike the latter. (Le Figaro, 2008)

In conclusion, this class was named Impacts of Climate Change on Coasts because of the frequency of association between discourse on marine submersion and on climate change. Temporally associated with the pre-Xynthia period, this class contains technical discourse delivered mainly by scientific actors addressing future coastal problems. This class is consistent with the emergence phase (Castro, 2012) where a minority of people, in this case scientists, are beginning to inform and warn about marine submersion. It can also be interpreted as the pre-problem stage of Downs (1972), characterised by occasional accounts of experts' concerns.

\section{Xynthia and coastal storms (Class 2)}

Xynthia and coastal storms (Class 2), represented 792 text segments (19.06\% of the analysed corpus), and was associated with the variables "national newspapers" $(\chi 2=$ 25.34), more specifically the following papers: "Le Figaro" $(\chi 2=40.28)$, "Les Echos" $(\chi 2=9.73)$, "La Croix" $(\chi 2=6.13)$. It was also associated with the geographical area

\footnotetext{
${ }^{6}$ Grenelle of the Sea.
} 
"France in general" $(\chi 2=6.13)$. No temporal variable ("before" or "after" Xynthia) was associated with this class.

This second class is organized around discourses focusing on the description of coastal storm events and their impacts. There is also a lexicon of weather-related terms such as tide, wind, vigilance, rain, depression, and atmospheric. It is also within this class that submersions and floods are referred to, through terms such as wave, water, river, sea as well as action verbs such as overflow, submerge, invade, swell and flood. Other action verbs mark the suddenness and violence of these phenomena: provoke, strike, destroy, unleash, trigger and pull. The human and material consequences - damage, death, victim, loss, balance - are also mentioned, as well as the various physical protection measures dam, cofferdams, pump, watertight doors and cranks. Here is an example of this discursive content:

While the trauma of Storm Xynthia is in everyone's memory, the boroughs have embarked on a major project to rebuild dykes. The weather is not stormy and yet the waves are hitting the dyke head on. [...] During the night of 27-28 February 2010, this wall exploded under the violence of Storm Xynthia. The sea infiltrated mainly through the marshes on the north façade. Thousands of homes were flooded, two persons died and an island was cut in two: the drama is still in everyone's mind, almost nine years later. (Le Figaro, 2018)

As the above excerpt indicates, the memory and remembrance of Xynthia mark other similar events: "the memory of Storm Xynthia remains vivid"; "Sad memories. No one has forgotten Xynthia, its forty-seven dead"; "There will be a 'before and an after Xynthia' as there was, in terms of industrial risk, a 'before and an after-AZF' ${ }^{, 7 \% .}$. Xynthia

\footnotetext{
${ }^{7}$ The AZF factory in Toulouse was a chemical plant (AZote Fertilizers) that exploded on September 21, 2001, causing significant damage, injury and loss of life.
} 
is omnipresent as "the storm of reference". Places typically associated with this class are places that have been strongly affected by Xynthia such as the villages of Faute-sur-mer or Aiguillon-sur-Mer, or the regions Vendée or Charente-Maritime. In the same vein, this class also includes temporal references to the storm that took place during the night of 27 to 28 February 2010. Considering that references to Xynthia are not exclusively associated with any particular one of the time periods analysed, the continuous mention of the event suggests that Xynthia has been objectified as a collective reference, a shared memory of what marine submersions are and what they are capable of.

The interpretation that Xynthia objectified marine submersions -i.e., remained a prototype of these phenomena -is also supported by article titles when these raise concerns about the possibility that similar phenomena will happen in the future ("Very large tides, Xynthia's shadow hovers", "Is another Xynthia possible?", "The Xynthia syndrome is blowing over Port-Rhu”) or suggest that Xynthia sparked awareness of our vulnerability to marine submersion ("With Xynthia, we had the impression of discovering marine submersions", "Xynthia, a starting point", "Xynthia was finally a trigger", "Xynthia, a warning signal") as well as of the strategies put in place to deal with it: "Xynthia teaches us to better protect ourselves. Urbanisation, prevention, evacuation procedures... France learns lessons from the deadly storm", "We must do everything we can to avoid a second Xynthia”. Here is an excerpt of this discursive content:

Do we really need to caulk in a storm? After Xynthia and its twenty-nine ${ }^{8}$ victims in 2010, a Senate report criticised this instruction. However, on Monday, it is still what was recommended by the authorities. What should we think? How to react in the event of a storm? Caulking? Since Xynthia, this advice stirs up the worst

\footnotetext{
${ }^{8}$ The number "29" here refers to the number of deaths in the department of Vendée and not in the whole of France.
} 
memories. Of the 29 victims in the Vendée, most were trapped in their flooded homes. (Ouest France, 2014)

This is the only class that is not associated with a specific time period, illustrating that this storm became a societal memory reference point for newer coastal phenomena. Whereas storms are a seasonal phenomenon, the enduring and non time-specific reference to Xynthia since 2010 shows that it became an archetype for the presentation of marine submersion risk by the press.

\section{Implementation of national risk management plans (Class 1)}

Representing 1538 text segments (38.07\% of the analysed corpus) Class 1 , Implementation of national risk management plans, is associated with the variables "years of publication 2010-2013" ( $\left.\chi^{2}=90.31\right)$, and the newspapers "Les Echos" ( $\chi 2=$ 9.73), "Var-Matin" $(\chi 2=8.01)$ and "Atlantic coast" $(\chi 2=4.01)$.

This class refers to discourses describing the implementation of public policies for the management of risk, as well as their consequences on the development of the territory. Various plans are thus evoked in press articles: flood prevention action programme, local urban planning, municipal safeguard plan etc. These public policies are supported by normative and legal frameworks - as indicated by some terms characteristic of this class such as rule, law, norm, right and decree - aiming at imposing a set of urban planning measures. These include a ban on a number of constructions, an obligation for some owners to sell their homes, expropriation and relocation. Here is an example of this discursive content:

This means new town planning rules must be applied. No more residential or accommodation buildings may be built in these areas. But existing buildings can be extended, subject to conditions. Other constructions - other than dwellings and 
accommodation installations - may be allowed, subject to new standards. It is no longer possible to build new sensitive establishments (schools, retirement homes, etc.) that would increase the number of people exposed to risks. (Ouest France, 2011)

This class gathers the actions and discourse of national political actors who represent the state or the government. Typical press articles in this class refer to the Ministry of Ecology, senators and parliamentarians as well as national politicians such as Jean-Louis Borloo or Ségolène Royal. They are also structured around a technocratic characterisation of risk. We find a highly technical lexicon associated with, on the one hand, the assessment of the hazard - zone, analysis, atlas, diagnosis, map, delimitation and perimeter; and, on the other hand, on prevention and protection of the population security, disaster, alert message, crisis management, information, emergency, refuge, precaution and disaster. These press articles highlight the notion of "risk culture" as a key to risk management. "Xynthia: "Make the risk culture grow", "awaken this 'risk culture"'. Here is an example of this discursive content:

Risk culture is being reinforced. Reinforcement and/or raising of dykes, fattening and/or protection of dunes, but also of risk culture. Anything that contributes to raising awareness of the risk and dangers associated with the ocean is at least as important as the "shields" that block the vagaries of the ocean. Risk culture is therefore an integral part of the toolbox. To support it, there is an arsenal of small and big things, such as the development of a communal safeguard plan, of course, which enables everyone to know what to do in the event of flood alert. In La Fautesur-Mer, we even imagined the creation of referents, in charge of accompanying the most fragile in the event of climatic shocks. (Ouest France, 2018) 
The discourse that was selected as part of this class describes two different moments associated with the crisis triggered by Xynthia. Initially, political discourse about the decisions taken to manage the current crisis is reported in the newspapers. Then articles turn to one of the state responses to prevent this type of natural hazard through various plans and the development of risk management tools. This state response as part of the crisis management can be interpreted as part of the institutionalisation phase (Castro, 2012). Generally, the result of international commitments (e.g., the Kyoto protocol), in the case under analysis here the observed changes in institutional discourse were triggered by a natural catastrophe. In terms of media attention cycle (Downs, 1972) this class describes a maintenance stage, following the alarmed discovery stage and characterized by political action and policy implementation.

Resistance, conflicts and local public debates (Class 4)

Representing 847 text segments (20.97\% of the analysed corpus), Resistance, conflicts and local public debates, (Class 4) was associated with the following variables: "years of publication 2014-2018" $\left(\chi^{2}=66.27\right)$, "regional newspapers" $\left(\chi^{2}=235.0\right)$, as well as "Ouest France" $(\chi 2=270.49)$ and "Atlantic coast" $(\chi 2=207.32)$.

This class depicts the local challenges facing the implementation of risk management plans. Such plans are the subject of public inquiries and meetings. Conducted by investigating commissioners, they are based on consultation with citizens. Thus, everyone can attend, is invited to adjudicate and give their opinion during meetings.

The discourse of opposition found within this class is primarily presented by local actors. Thus we find various elected representatives of the municipal council as members of parliament or mayors, several of whom are identified - e.g., Jean Lepetit, François 
Lobit. Also quoted are civil society organisation adherents, members, presidents of associations such as $A D E P T^{9}, 1^{\prime} A M P R I^{10}$, or Les Amis du Littoral like Bertrand Roy and Michel Flaux. Finally, several articles highlight inhabitants, especially shopkeepers, worried about the potential negative impact of the plans on their activity.

These various actors denounce the state's refusal to take into account the specificities of each municipality as well as the consequences of these public policies i.e., marine submersion risk prevention plan, coastal risk protection plan - of local territories, particularly in terms of economic constraints and impacts on tourism. These disputes, found in a set of terms such as unfavourable, opposition, polemic, anger, are expressed through different means of struggle: petitions, mobilizations, demonstrations, as well as lawsuits - court, appeal and ruling. Here is an example of this discursive content:

Marine submersion: anger outbreaks in Carnac. The elected representatives of the coastal communes of the Auray region protest against the coastal risk prevention plan prescribed by the State. "Unacceptable". That is what Olivier Lepick, mayor of Carnac, said facing the coastal municipalities elected representatives, who joined forces to support him in his fight against the Ministry of Ecology. "Like Oleron or Ré, Carnac is facing an autistic State that passes legislation by decree and poses a terrible threat to the tourist economy of our territory". (Ouest France, 2015)

This fourth class has to do with social tension and debate arising some years after the storm. Such resistance has previously been described as part of the generalization phase (Castro, 2012). During this process, society might share a desired goal - the control of the coastal vulnerabilities in this case. Still the different

\footnotetext{
${ }^{9}$ Association Pour Le Développement Économique Et La Promotion Touristique

${ }^{10}$ Association Monastérienne de Protection face aux Risques d'Inondations
} 
groups that compose this society might disagree on the means used to attain this goal. In this class we find various concerns regarding the institutional response to Storm Xynthia, voiced by elected leaders or associations, in a resistance type of response typical of the generalisation phase of normative social changes (Castro \& Batel, 2008; Castro, 2012).

Throughout the description of these four discursive classes, we have come across different argumentative positions, sometimes at odds with one another. The classes described above depict the emergence and evolution of institutional changes for climate change adaptation. The first of these social change phases - the emergence phase - is characterised by scientific discourse. Then during the institutionalization phase, we find political discourse coupled with technical considerations. And finally, during what we interpret as the generalization phase, we find discourse voiced by local political leaders and associations. Because this analysis reveals an evolving social debate heard through different voices, we present in the next section a frequency analysis of which social actors are used as a source for newspaper articles.

Actors represented in newspapers according to time period

[Insert figure 3 about here]

As shown in Figure 3, direct quotations from local politicians and scientists represent respectively $41.76 \%$ and $27.94 \%$ occurrences over the 13 years of press data under analysis. By contrast, national politicians, civil society organisation representatives 
and residents are mentioned but less frequently quoted in their own voice (respectively $11.47 \%, 12.35 \%$ and $6.47 \%$ ). However, when taking into account the distribution of this discourse across time, we find some voices are more typically heard in specific moments of the societal change in response to 'marine submersion'. For example, prior to Xynthia (2005-2009) scientists' discourse and, to a lesser extent, local politicians' is overrepresented.

Just after Xynthia (2010) we can observe a decrease in the frequency of articles directly quoting scientists, and a simultaneous increase of those citing national politicians. During this phase immediately following Xynthia, national politicians are more frequently used as a source. In 2012 their presence is seen to decrease in favour of local politicians, whose points of view are often presented through direct quotations. Finally, from 2013 on, local associations are more frequently cited as a source; from 2014 on, local residents also start receiving increased media attention.

\section{Discussion}

Storm Xynthia and the marine submersion it generated took place in 2010 on the Vendée and Charente coasts of France's Atlantic seaboard. These events led to many changes in the regulation of coastal risks in France (Chadenas et al., 2014) and still hold an important place in the French collective memory (Vinet et al., 2012). Through two studies analysing the production of French local and national newspapers between 2005 and 2018, we describe the different phases of societal debate associated with 'marine submersion' and related legal innovations during this period. Our press analysis allows us to describe how the public debate (as depicted in the French newspaper media) accompanied the emergence and amplification of 'marine submersion' as a risk 
(Kasperson et al., 1988), and triggered social and institutional change (Castro, 2012) to climate change adaptation.

Study 1 sought to establish how marine submersion reporting trends evolved in relation to Storm Xynthia (before the storm; during it; and since then) and according to issue attention stages (Downs, 1972). Study 2 analysed meanings and representations as well as the types of actors voicing their concerns, placing these in relation with phases of legal and institutional adaptation (Castro, 2012).

In terms of publishing patterns and media content we have demonstrated the utility of combining Down's media attention cycle stages (1972) and Castro's temporal approach to normative social change (2012) to draw lessons from a press analysis. The reporting phase "before" the storm (2005-2009) is driven by scientific discourse, using technical terminology to address the future coastal impacts of climate change. Characterized by low reporting frequencies of a minority discourse, this can be described as an emergence phase (Castro, 2012) or pre-problem stage (Downs, 1972). After the storm takes place, a first peak in reporting frequencies is observed (2010-2013), containing national and local politicians' discourse about the Xynthia disaster management as well as reporting the State response to coastal hazards through the implementation of risk management plans and tools. This can be characterized as the institutionalisation phase (Castro, 2012) or the alarmed discovery stage (Downs, 1972). Finally, a third reporting period is observed (2014-2018) in which public participation and resistance are covered, together with local conflicts about how new risk management legal tools - proposed in response to Storm Xynthia - oppose local politicians, associative stakeholders and residents. During this third period a second reporting peak is observed that is not well characterized as a maintenance stage (Downs, 1972) but is well explained as the third phase of the normative social change model (Castro, 2012): the generalisation 
phase. During this phase the difficulties in interpreting new laws and regulations start to be felt during their application, often opposing social groups with conflicting local interests and different interpretations of how the new laws should be applied in a particular case (Castro \& Mouro, 2011). This description of how new laws and regulations change the intergroup dynamics at the local level is capable of explaining why we find a second peak in newspaper reporting during the implementation phase of new climate change adaptation regulations.

Concerning the emergence of a new type of natural risk, these studies illustrate how Xynthia contributed to the social amplification of marine submersion risks in France. The Social Amplification of Risk framework (SARF) posits that a hazard might remain largely unknown in the absence of the societal recognition, or signal, of its existence (Kasperson et al., 1988; 2003). The heatwave that hit France in 2003 (Poumadère et al., 2005) is a paradigmatic example of how an initially ignored - or attenuated - risk suddenly becomes amplified, generating important social and institutional responses - i.e., new laws and regulations - so as to reduce future vulnerability. Such a significant societal response must be accompanied by changes in how the media refers to these new risks. Their initial idea, possibly mentioned occasionally by scientists as in the case of coastal risks, becomes galvanised around an identifiable issue that dispenses supplementary introduction only once they become socially objectified (Bertoldo, 2021). The extent to which the marine submersion risk has been objectified over the Storm Xynthia can be noted in the use of Xynthia as a mnemonic reference, a social memory, or an archetype of this type of coastal events even 10 years later.

These findings support the argument made by coast inhabitants and risk managers that only when "something happens" can risk preparedness be justified (Bertoldo et al., 2021). In the absence of a threat that they can objectify, represent, and communicate 
about, local stakeholders communicate about marine submersion in rather abstract terms. The existence of a risk is recognized when they witness it and feel directly concerned and affected by it (Bertoldo et al., 2021).

Storm Xynthia and its consequences are a case study of how a "new" risk tests the flexibility and resilience of societies faced with climate change adaptation. Considering the 'glocal' characteristics of climate change - a global phenomenon with contextualized impacts - this study illustrated how our media discourse evolve with, or in response to, the adaptations our institutions make to take into account new types of threats.

\section{Declaration of Conflicting Interests}

The authors have declared no potential conflicts of interest with respect to the research, authorship, and/or publication of this article.

\section{Funding}

This work received funding from the European Union - FEDER programme (DIGUE 2020 project) and from Labex OT-Med (n ANR-11-LABX-0061). 


\section{References}

Bakir, V. (2005) "Greenpeace v, Shell: Media Exploitation and the Social Amplification of Risk Framework (SARF)," Journal of Risk Research 8(7-8): 678-91.

Bertoldo, R. (2021). A comparative frame for a contextualised analysis of local natural risk management. International Journal of Disaster Risk Reduction, 52, 101945. https://doi.org/10.1016/j.ijdrr.2020.101945

Bertoldo, R. Guignard, S. Dias, P. Schleyer-Lindenmann, A. (2021). Coastal inconsistencies: An analysis of how coastal flood risk is understood and anticipated in southern France. International Journal of Disaster Risk Reduction, 52. Advanced online publication.

Billig, M. (1991). Ideology and Opinions. Sage Publications.

Billig, M., Condor, S., Edwards, D., Gane, M., Middleton, D., \& Radley, R. (1988). Ideological Dilemmas. Sage Publications.

Breilh, J.-F., Chaumillon, E., Bertin, X., \& Gravelle, M. (2013). Assessment of static flood modeling techniques: application to contrasting marshes flooded during Xynthia (western France). Natural Hazards Earth System Sciences, 13(6), 15951612. https://doi:10.5194/nhess-13-1595-2013

Breakwell, G. M. (2014). The Psychology of Risk. Cambridge: University Press.

Britel, M., Bourguignon, M., \& Preau, M. (2020). Radiation protection in mammography for breast cancer screening: not covered by the French press. Public Health, 183, 119-121. https://doi.org/10.1016/j.puhe.2020.04.006

Burgess, A. (2012). Media, Risk, and Absence of Blame for "Acts of God": Attenuation of the European Volcanic Ash Cloud of 2010. Risk Analysis, 32(10), 1693-1702. https://doi:10.1111/j.1539-6924.2012.01803.x 
Caillaud, S., Kalampalikis, N., \& Flick, U. (2011). The social representations of the Bali climate conference in the French and German media. Journal of Community and Applied Social Psychology, 22 (4). https://doi: 10.1002/casp.1117

Calvet, F, \& Manable, C. (2015). Rapport d'information du Sénat: Xynthia 5 ans après : pour une véritable culture du risque dans les territoires. [Senate Information Report: Xynthia 5 years later: for a true culture of risk in the territories]. Retrieved from https://www.senat.fr/rap/r14-536/r14-5361.pdf.

Carvalho, A. (2007) Ideological cultures and media discourses on scientific knowledge: Re-reading news on climate change. Public Understanding of Science 16(2), 223243.

Castro, P. (2012). Legal Innovation for Social Change: Exploring Change and Resistance to Different Types of Sustainability Laws. Political Psychology, 33(1), 105-121. https://doi.org/10.1111/j.1467-9221.2011.00863.x

Castro, P., \& Batel, S. (2008). Social representation, change and resistance: On the difficulties of generalizing new norms. Culture \& Psychology, 14(4), 475-497. https://doi: 10.1177/1354067X08096512

Castro, P., \& Mouro, C. (2011). Socio-psychological processes in dealing with change in the community: Insights gained from biodiversity conservation. American Journal of Community Psychology, 47(3), 362-373. https://doi: 10.1007/s10464-010-93910

Castro, P., \& Mouro, C. (2016). Self-Other Relations in Biodiversity Conservation in the Community: Representational Processes and Adjustment to New Actions. Journal of Community \& Applied Social Psychology, 26(4), 340-353. https://doi: 10.1002/casp. 2267 
Chadenas, C., Creach, A., \& Mercier, D. (2014). The impact of Storm Xynthia in 2010 on coastal flood prevention policy in France. Journal of Coastal Conservation, 18(5), 529-538. https://doi: 10.1007/s11852-013-0299-3

Chaumillon, E., Bertin, X., Fortunato, A.B., Bajo, M., Schneider, J.-L., Dezileau, L., Walsh, J.P., Michelot, A., Chauveau, E., Créach, A., Hénaff, A., Sauzeau, T., Waeles, B., Gervais, B., Jan, G., Baumann, J., Breilh, J.-F., \& Pedreros, R., (2017). Storm-induced marine flooding: lessons from a multidisciplinary approach. EarthScience Reviews, 165, 151-184. http://doi.org/10.1016/j.earscirev.2016.12.005.

Creach, A., Pardo, S., Guillotreau, P., \& Mercier, D. (2015). The use of a micro-scale index to identify potential death risk areas due to coastal flood surges: lessons from Storm Xynthia on the French Atlantic coast. Nat Hazards, 77(3), 1679-1710. https://doi:10.1007/s11069-015-1669-y

DeFleur, M. (1966). Theories of Mass Communication. New York: McKay Company.

Downs, A. (1972). Up and down with ecology: The issue-attention cycle. The Public Interest, $28,38-51$.

Fonte, D., Colson, S., Côté, J., Reynaud, R., Lagouanelle-Simeoni, M. C., \& Apostolidis, T. (2017). Representations and experiences of well-being among diabetic adolescents: Relational, normative, and identity tensions in diabetes selfmanagement. Journal of Health Psychology. 17(2), 194-210. https://doi:10.1177/1359105317712575

Fouillet, A., Rey, G., Wagner, V., Laaidi, K., Empereur-Bissonnet, P., et al. (2015). Has the impact of heat waves on mortality changed in France since the European heat wave of summer 2003? A study of the 2006 heat wave. International Journal of Epidemiology, 37(2), 309-317. https://doi: 10.1093/ije/dym253 
Garnier, E., \& Surville, F. (2010). La tempête Xynthia face à l'histoire. Submersions et tsunamis sur les littoraux français du Moyen Âge à nos jours. [Storm Xynthia in the face of history. Floods and tsunamis on the French coasts from the Middle Ages to the present day]. Le CroîtVif.

Idoiaga Mondragon, N., \& Belasko Txertudi, M. (2019). Understanding menstruation: Influence of gender and ideological factors. A study of young people's social representations. Feminism \& Psychology, 29(3), 357-373. https://doi.org/10.1177/0959353519836445

Idoiaga, N., Berasategi, N., Eiguren, A., \& Picaza, M. (2020). Exploring Children's Social and Emotional Representations of the COVID-19 Pandemic. Frontiers in Psychology, 11(1952). https://doi: 10.3389/fpsyg.2020.01952

IPCC (2014). Climate Change 2014: Mitigation of Climate Change; Working Group III Contribution to the Fifth Assessment Report of the Intergovernmental Panel on Climate Change. Cambridge Univ. Press, New York, NY.

Jaspal, R., \& Nerlich, B. (2012). When Climate Science Became Climate Politics: British Media Representations of Climate Change in 1988. Public Understanding of Science, 23(2), 122-141. https://doi.org/10.1177/0963662512440219

Jaspal, R., Nerlich, B., \& Koteyko, N. (2012). Contesting Science by Appealing to Its Norms: Readers Discuss Climate Science in the Daily Mail. Science Communication, 35(3), 383-410. https://doi.org/10.1177/1075547012459274

Jensen, E., \& Wagoner, B. (2009). Continuing Commentary: A Cyclical Model of Social Change. Culture \& Psychology, 15(2), 217-228. https://doi.org/10.1177/1354067x08099624

Kalampalikis, N. (2003). L'apport de la méthode Alceste dans l'analyse des représentations sociales [The contribution of the Alceste method in the analysis of 
social representations]. In J.C. Abric (Ed.), Méthodes d'étude des représentations sociales (pp. 147-163). Erès.

Kalampalikis, N., \& Moscovici, S. (2005). Une approche pragmatique de l'analyse Alceste [A Pragmatic Approach to Alceste Analysis]. Les Cahiers Internationaux de Psychologie Sociale, 66(2), 15-24. https://doi:10.3917/cips.066.0015.

Kasperson, J., Kasperson, R. E., Pidgeon, N. and Slovic, P. (2003) "The Social Amplification of Risk: Assessing Fifteen Years of Research and Theory," in N. Pidgeon, R. E. Kasperson and P. Slovic (eds) The Social Amplification of Risk, pp. 13-47. Cambridge University Press.

Kolen, B., Slomp, R., van Balen, W., Terpstra, T., Bottema, M., \& Nieuwenhuis, S. (2010) Learning from French experiences with Storm Xynthia - Damages after a flood. ISBN 978-90-77051-77-1.

Krien, N., \& Michel-Guillou, E. (2014). Place des risques côtiers dans les représentations sociales du cadre de vie d'habitants de communes littorales. [The place of coastal risks in the social representations of the living environment of inhabitants of coastal communities]. Les Cahiers Internationaux de Psychologie Sociale, 101, 101-122. https://doi: 10.3917/cips.101.0101.

Ledouble H., \& Marty E. (2019). The 2016 presidential primaries in the United States: a quantitative and qualitative approach to media coverage, Studia Neophilologica, 91(2) 199-218. https://doi: 10.1080/00393274.2019.1616219

Lelaurain, S., Fonte, D., Aim, M. A., Khatmi, N., Decarsin, T., Lo Monaco, G., \& Apostolidis T. (2018). “One doesn't slap a girl but...”: Social representations and conditional logics in legitimization of intimate partner violence. Sex Roles, 78(9), 637-652. https://doi:10.1007/s11199-017-0821-4 
Michel-Guillou, E., Lalanne, P-A. \& Krien, N. (2015). Hommes et aléas : appréhension des risques côtiers par des usagers et des gestionnaires de communes littorales. [People and hazards: apprehension of coastal risks by users and managers of coastal communities]. Pratiques Psychologiques, 21(1), 35-53.

Manchaiah, V., Ratinaud, P., \& Andersson, G. (2018). Representation of Tinnitus in the US Newspaper Media and in Facebook Pages: Cross-Sectional Analysis of Secondary Data. Interactive Journal of Medical Research 7(1):e9. https://doi: 10.2196/ijmr.9065.

Moscovici, S. (2008). Psychoanalysis: Its image and its public. Polity Press.

Mulot, V. (2015). Les submersions marines : nouveaux enjeux, nouvelles pratiques juridiques [Marine submersions: new issues, new legal practices]. Thèse de doctorat en droit public. Aix-en-Provence : Aix-Marseille Université.

Navarro, O., Restrepo-Ochoa, D., Adriana Muñoz-Duque, L., Zapa-Perez, K., Ameline, A., et al. (2020). Determinants of coping strategies in two types of natural hazards: Flash floods and coastal flooding. International Journal of Disaster Risk Reduction, 46, 101514. https://doi: 10.1016/j.ijdrr.2020.101514Neca, P., \& Castro, P. (2012). Representações da deficiência na imprensa portuguesa: Hegemonia e emancipação. Estudos Em Comunicação, 12, 367-386.

Poumadère, M., Bertoldo, R., Idier, D., Mallet, C., Oliveros, C., \& Robien, M. (2015). Coastal vulnerabilities under the deliberation of stakeholders: The case of two French sandy beaches. Ocean \& Coastal Management 105, 166-176.

Poumadère, M., Mays, C., Le Mer, S., \& Blong, R. (2005). The 2003 Heat Wave in France: Dangerous Climate Change Here and Now. Risk Analysis, 25(6), 14831494. https://doi.org/10.1111/j.1539-6924.2005.00694.x 
Pidgeon, N., Kasperson, R., Slovic, P. (2003). The Social Amplification of Risk. Cambridge University Press.

Prieur, L., \& Leost, R. (2015). La prise en compte de la submersion marine par la loi littoral [The taking into account of the marine submersion by the coastal law]. VertigO - la revue électronique en sciences de l'environnement. https://doi.org/10.4000/vertigo.15823

Reinert, M. (1983). Une méthode de classification descendante hiérarchique. Application à l'analyse lexicale par contexte [A method of a top-down hierarchical classification. Application to lexical analysis by context]. Cahiers de l'analyse des données, 7, 187-198.

Reinert, M. (1986). Un logiciel d'analyse lexicale (ALCESTE) [a lexical analysis software (ALCESTE)]. Cahiers de l'analyse des données, 4, 471-484.

Uzelgun, M. A., \& Castro, P. (2015) Climate Change in the Mainstream Turkish Press: Coverage Trends and Meaning Dimensions in the First Attention Cycle. Mass Communication and Society, 18, 730-752. https://doi: $10.1080 / 15205436.2015 .1027407$

Vinet, F., Defossez, S., Rey, T., \& Boissier, L. (2012). Le processus de production du risque « submersion marine » en zone littorale: l'exemple des territoires «Xynthia ». [The production process of the "marine submersion" risk in coastal areas: the example of the "Xynthia" territories.] Norois, 222(1), 11-26. 